\title{
Soil Pollution and Remediation Problems in Turkey
}

\author{
E. Burcu Özkaraova Güngör \\ Ondokuz Mayls University \\ Turkey
}

\section{Introduction}

Turkey has been undergoing significant economic transformations since the 1980s. The adopted structural reform programme was based on outward-looking trade policies. The growth of industry and services, reflecting from time to time high rates among the OECD countries, resulted in a decline in the share of agriculture in the Gross National Product. This, however, does not mean that the importance of agriculture is continuing to decline, because investigations in rural infrastructure and implementation of agricultural policy, supporting improved productivity, are carried out by the government.

The rapid growth in industrial investments, unfortunately, increased the pressure on environment, which was recognized by the Turkish government. Thus, the Prime Ministry Undersecretariat for Environment was founded in 1978, later on replaced by the Ministry of Environment in 1991. This change led to a diversification of the Ministry's responsibilities and an expansion of its staff and empowered the administration power to implement and enforce policies for the protection and conservation of the environment (Okumuş, 2002). Besides developing environmental policies and strategies, other duties of the Ministry are to coordinate environmental activities on local, national and international levels, issuing environmental licenses and data collection. Currently, provincial branches of the Ministry are dealing with environmental tasks in all 81 provinces located in seven regions, namely the Mediterranean, Aegean, Marmara, Black Sea, Central Anatolia, Eastern Anatolia and South Eastern Anatolia. Besides many others, the main environmental tasks of the provincial branches are to take cautions for the prevention and minimization of pollution, to inspect all kind of activities that might threaten the environment and cause to possible pollution in soil and water resources, and to control the facilities approved by the local authorities. Responsibilities of provincial and local authorities, dealing with environmental matters like waste management and pollution prevention have expanded. Especially, the increased power of municipalities obligates them to improve the infrastructure of waste management systems, like sewage and other waste services (collection, treatment and disposal) according to the standards set by the Environmental Law and regulations.

The Environmental Law, which stems from the 1982 Constitution, came into force in 1983. According to the Constitution, each citizen has a right to live in a healthy and balanced 
environment and that the citizens and the Government are responsible in the protection and improvement of the environment. The Environmental Law, besides these basic principles, states that all measures should be taken to minimize pollution in every economic activity. For the implementation of the Environmental Law, several regulations, fully recognizing the principles of environmental management, were published in the official gazette since 1983. The first issued regulations are:

- $\quad$ Air Quality Control Regulation (1986)

- Noise Control Regulation (1986)

- Water Pollution Control Regulation (1988)

- $\quad$ Solid Waste Control Regulation (1991)

- Environmental Impact Assessment Regulation (1993)

- Hazardous Waste Control Regulation (1995)

After Turkey became a candidate state of European Union (EU) at the Helsinki European Council in 1999, the Accession Partnership, which was proposed by the European Commission in 2000, also identified the environmental priority areas. Besides many others, one of the priority areas was to ensure environmental protection, implementation of the acquis with particular attention to the framework legislation, horizontal legislation and legislation on nature protection, water quality and waste management. Thus, the adaptation of EU directives into the national legislation resulted in the revision of present legislations and enforcement of many others including those on soil protection and pollution control (Okumuş, 2002).

\section{Environmental Policies and Strategies}

Turkey, recognizing the pressures on the environment from rapid economic growth, took the first step for the development of an environmental policy in the Third Five-Year National Development Plan (1973-1977) with the inclusion of the 'Environmental Management' concept. For the implementation of environmental protection issues and creating solutions on local and national level, the Undersecretariat for Environment was founded. However, the enforcement of an environmental policy has been difficult for years, since priority was given to industrial investments. 'Sustainable Development' was adopted as the central concept for the period 1991-1996 (Sixth Plan), and 'Protection and Improvement of the Environment' was a major objective for the period 1996-2000 (Seventh Plan) (OECD, 2000). The major objectives, principles and policies of the Seventh Five Year National Development Plan were determined as (State Planning Organization, 1998):

- emphasizing pollution prevention rather than clean-up;

- using an appropriate combination of economic and regulatory instruments;

- developing regional and eco-basin strategies;

- strengthening the system of environmental management;

- ensuring that policies and solution are in accordance with EU norms and international standards;

- revising and enhancing the financing system for environmental protection, management and improvement;

- promoting environmental awareness through formal and non-formal channels,

- ensuring compatibility between economic development and environmental protection. 
Nevertheless, the Seventh Five-Year National Development Plan noted that environmental concerns have not been adequately incorporated into all economic and social decisions or in legislative/organizational arrangements till then (State Planning Organization, 1998). Thus, to implement the objectives of the Seventh Development Plan, a National Environmental Action Plan (NEAP) was prepared by the State Planning Organization (DPT) in cooperation with the Ministry of Environment and financial support of the World Bank. Under the authority of the Prime Ministry, State Planning Organization takes strategic decisions on investment priorities based on investment requirements in all areas of economic activity. The State Planning Organization has the power to require that environmental considerations are incorporated into investment proposals, which are totally or partially financed from public funds (Okumuş, 2002).

The Preparation process of NEAP started in 1995 with tremendous efforts of nineteen working groups representing local and national governmental authorities, municipalities, the private sector, academia, non-governmental organizations, members of media and donors (the UNDP and World Bank). These groups produced reports and recommendations on air quality, natural, historical and cultural heritage; demography and public health; soil, water, solid waste, wastewater, marine resources, land use and coastal zone management; economic and financial issues; legal, institutional and regulatory frameworks; education and participation; and noise pollution (State Planning Organization, 1998). With the synthesis of NEAP from the working papers, the problem areas and action categories were set (Table 1).

Soil protection and pollution issues were included in the NEAP under 'Soil and Land Use' and 'Hazardous Wastes' headings. Soil protection, which is mainly considered as an agricultural concept, is mostly based on prevention of erosion, desertification, salination and misuse of agricultural land. For this purpose, the development of agricultural support policies and rural development policies; the preparation of action plans for the prevention of soil erosion, desertification etc. are accepted as mandatory actions (Annex 1). Land use decisions should be coupled with soil suitability classifications. Therefore, the preparation of more precise inventories of land and soil qualifications is one of the main targets. For the implementation of these action plans, the Soil Conservation and Land Improvement Law and the Regulation on Implementation of Soil Conservation and Land Improvement Law were enforced in 2005 after the enforcement of the Regulation for the Protection and Improvement of Agricultural Land in 2003. Each of these put an emphasis on the need of soil qualification inventories and maps to enable proper use of land.

Classification and mapping for Turkey's soil have been made by the General Directorate of Soil and Water, today known as the General Directorate of Rural Services since 1950s. The first prepared map was the Turkey General Soil Map (1:800 000 scale) followed by the Turkey Development Soil Map (1:25 000 scale). With the evaluation of data, like depth, slope, stoniness, erosion degree etc., two maps, the Soil Resource Inventory Map (1:100 000 scale) and the Watershed Soil Map (1:200 000 scale) and Report was developed. From 1987 onwards, maps were prepared from the results of the Turkey Development Soil Map at a scale of 1.100 000. With the consultation of the General Directorate of Rural Services and the surveys, a map named the Turkey Soil Zones Map (1:2 000000 scale) was also made (Keskin, 2001). However, the need for the development of more precise smaller-scale maps continues. 


\begin{tabular}{|c|c|}
\hline Problem Areas & Coverage \\
\hline Population/Urbanization & Quality, Quantity, Density, Movements \\
\hline Air Quality & Monitoring, \\
\hline $\begin{array}{l}\text { Energy Generation and } \\
\text { Consumption }\end{array}$ & $\begin{array}{l}\text { Production, Distribution, Consumption; Development of } \\
\text { New/Renewable Sources, Conservancy }\end{array}$ \\
\hline $\begin{array}{l}\text { Water and Wastewater } \\
\text { Management }\end{array}$ & Rivers; Seas; Lakes; Ponds, Groundwater, Wastewater. \\
\hline Solid and Hazardous Wastes & $\begin{array}{l}\text { Domestic; Industrial; Hazardous; Medical (Liquid, Solid, } \\
\text { Gas) }\end{array}$ \\
\hline Noise & Traffic; Industry \\
\hline Soil and Land Use & $\begin{array}{l}\text { Erosion; Pollution; Misuse of Agricultural Lands; } \\
\text { Desertification; Salination; Mining Industry, Agricultural } \\
\text { Technology. }\end{array}$ \\
\hline Forests/Vegetative Cover & Forests; Steppes; Ranges and pastures \\
\hline $\begin{array}{l}\text { Marine Resources, Coastal } \\
\text { Zones and Sensitive } \\
\text { Environments }\end{array}$ & $\begin{array}{l}\text { Wetland; Shore; Island; Aquatic products, Mountain; } \\
\text { Highland, Sand Dunes }\end{array}$ \\
\hline $\begin{array}{l}\text { Historical, Cultural and } \\
\text { Natural Heritage }\end{array}$ & $\begin{array}{l}\text { Monuments; Ruins; Natural Formations; Endemic Plants } \\
\text { Under the Threat of } \\
\text { Extinction; Animals; Value Judgments }\end{array}$ \\
\hline Action Categories & Areas \\
\hline Policies & Economic, Social, Cultural and Sectoral \\
\hline Institutional Reform & $\begin{array}{l}\text { Ministries and Related Organizations; professional } \\
\text { Organizations; } \\
\text { Voluntary Organizations; Private and Public Sector } \\
\text { Enterprises; Cooperatives; Management }\end{array}$ \\
\hline Legislation & The Constitution, Laws, Regulations, By-laws; Circulars \\
\hline $\begin{array}{l}\text { Economic \& Financial } \\
\text { Measures }\end{array}$ & $\begin{array}{l}\text { Taxes, Incentives, Subsidies, Funds; Fines, Voluntary } \\
\text { Contributions }\end{array}$ \\
\hline Education \& Awareness & Non-formal and Formal Education; Arts; Religion \\
\hline Participation & International, National and Local \\
\hline Specific Tools & $\begin{array}{l}\text { Planning (Urban Development, Environment, Sectoral } \\
\text { and Action Plans); Monitoring and Supervision; } \\
\text { Standardization; EIA, Data Collection }\end{array}$ \\
\hline R \& D & $\begin{array}{l}\text { Research; Technique and Technology Development; } \\
\text { Monitoring and Transfer }\end{array}$ \\
\hline
\end{tabular}

Table 1. Problem Areas and Action Categories Used as Basis for Sectoral Options. (State Planning Organization, 1998)

Causes and facts of soil pollution are considered in more detail in the Hazardous Waste Management Report of NEAP rather than in the Land Use Report, which only proposes survey about contaminated areas (Ongan, 1997; Zanbak and Bayazit, 1997). Zanbak and Bayazit Tugal state in their report on hazardous waste management, that the effect of improper disposal of hazardous wastes on soil quality is not known since measurements on possibly contaminated areas are not performed. Policies of NEAP on hazardous waste 
management, includes rehabilitation issues of old waste dumps, besides emphasizing minimization, recycling and recovery of hazardous wastes and hazardous waste treatment. NEAP also points to a preparation of programmes for the improvement of polluted areas and establishment of an inventory of polluted sites (Annex 2).

Soil and water resources commission report on 'Use and Management of Watershed,' which was also used for the Eighth Five-Year National Development Plan (2001-2005), reflects the causes and status of soil pollution and proposes development of programmes and policies for the improvement of soil resources (State Planning Organization, 2001). A more detailed strategy for soil pollution management was defined in the commission report of Ninth FiveYear National Development Plan (2007-2013). The strategy is to prepare a national programme, which enables the development of methods and techniques for the identification, investigation, classification and finally remediation of polluted areas in accordance with the Soil Protection Strategy of EU' (State Planning Organization, 2006a). Recommended tasks and precautions for the minimization of soil pollution are;

- determination of polluted water and soil areas including areas with contamination risk,

- risk classification of polluted areas,

- taking remedial actions for the clean-up of polluted areas,

- implementation of projects and programmes for soil and water pollution prevention,

- $\quad$ preparation of emergency plans for areas with high contamination risk.

For the prevention and control of soil pollution several regulations have been enforced after 2000, which were also a part of the Environmental Screening Process of EU.

\section{Legal Framework}

Turkey has many legislative elements that recognize the principles of pollution prevention and environmental management. The Environmental Law (1983) defines these principles and necessary activities, which are to protect and improve the environment, and to prevent and solve environmental problems. The Law prohibits the direct discharge of wastes into the receiving environment. It embodies the 'polluter pays' principle and set forth the concept of 'absolute liability' to enforce it. It sets monetary and imprisonment penalties in circumstances of violation of prohibitions and standards presented in the Law and regulations. According to the Law, procedures to be followed, plans to be created, standards to be met, and activities to be prohibited are specified in regulations. With the amendment of the Environmental Law in 2006, principles pertaining to the protection of soil and prevention of soil pollution are presented separately in a supplementary article. The introduction of higher fines and entry into force of the penal code's provisions, envisaging sanctions for environmental crimes are expected to improve inspection (Commission of the European Communities, 2006).

The publication of a regulation for the control of soil pollution took a very long time, since the importance of soil pollution was not early realized. However, the Solid Waste Control Regulation (1991), the Environmental Impact Assessment Regulation (1993), and especially the Hazardous Waste Control Regulation (1995) provided the necessary measures to inhibit soil pollution. Both the Solid Waste Control Regulation and Hazardous Waste Control Regulation provide a legal framework for the management of municipal solid wastes and hazardous wastes. The target of the Solid Waste Control 
Regulation is to prohibit direct or indirect delivery, storage, transportation, removal and similar activities of any kind of wastes and residuals into the environment in a way damaging the environment; to prevent the pollutants which exhibit a permanent effect on air, water and soil, deteriorate the ecological balance. Thus, it only prevents soil pollution arising from the infiltration of leachate into the subsurface due to improper storage and disposal of municipal solid wastes.

The purpose of the Hazardous Waste Control Regulation is to set legal and technical bases for the control and minimization of hazardous waste production, technical and administrative standards for the construction and operation of disposal sites, waste recycle, recovery and treatment plants. Similarly, it aims the prevention of direct or indirect disposal of hazardous wastes into the receiving environment. The regulation puts an emphasis on the necessity of reuse and recycling of hazardous waste. Under circumstances were reuse and recycling can not be carried out, appropriate disposal method is determined according to the characteristics of wastes and convenient technology.

Both regulations, especially the Hazardous Waste Control Regulation, have no direct implications related to contaminated sites. The Hazardous Waste Control Regulation defines hazardous wastes with respect to the lists categorizing hazardous wastes in relation to their sources and chemical composition. Thus, any site, which is polluted by any of these categorized hazardous wastes, can be seen as a contaminated site. However, difficulties arise from the lack of information for most of the chemicals in these lists regarding specific maximum concentration levels (NATO, 2002). The consignor, the hazardous waste producer, is responsible from the remediation of polluted area. Expenditures to cover all types of environmental hazards are compensated by the consignor. The consignor is also obliged to annually fill out a waste declaration form, which includes knowledge about the type, amount and composition of produced hazardous waste, and the applied recovery and disposal method. On the other hand, the Hazardous Waste Control Regulation does not specify actions for the identification, remediation and control of polluted site. It only states that wastes are physically, chemically or biologically treated prior to the disposal in a controlled landfill, and for the minimization of their impact on the environment.

In December 2001, the Soil Pollution Control Regulation, which is currently the major regulation related to soil pollution, was enforced. The purpose of this regulation is to specify the basic principles for taking the necessary precautions to prevent soil pollution. The regulation covers the technical and administrative principles related to activities like discharge, disposal and leakage of hazardous substances and wastes causing soil pollution, and the application of compost and sludge, arising from the treatment of domestic and industrial wastewater with domestic character, on soil. According to the regulation, the identification, investigation and monitoring of polluted sites are carried out by the Provincial Branches of the Ministry, which also determine the necessary measures to be taken. All expenditures are compensated by the polluter. Principles and methods for the identification, investigation, monitoring and remediation of contaminated sites are set forth by the Ministry. For the determination of pollution, limiting values for some heavy metals, a kind of indicative values, are given in Annex 1-A a), and target values for some inorganic and organic soil pollutants, which should be met after clean-up of site, in Annex 1A-b).

The Soil Pollution Control Regulation has many deficiencies with respect to its practicality regarding the identification, investigation, monitoring and remediation of contaminated 
sites. The regulation has been amended in 2005, but still, it does not provide any principle and/or method to be followed with regard to these matters. The major revisions required should cover the following points:

- The scope of regulation should be restricted to prevention of soil pollution and remediation of contaminated sites; legislative framework for the application of sludge and compost on soil should be presented in a separate regulation.

- Principles and methods to be followed with regard to identification, investigation, monitoring and remediation of contaminated sites should be included.

- Principles of investigation for remediation and planning of remediation should be adopted.

- Indicative levels, soil remediation intervention values and target values for serious contamination of soil/sediment and groundwater should be specified.

- Inorganic and organic substances covered by the list in Annex 1A should be extended.

- Sampling, sample preservation, sample pre-treatment, analysis standard and analysis techniques for the substances in list for soil and groundwater medium should be defined in a new annex.

- Data required for determining the remediation urgency and the remediation deadline for listed substances should be presented in a new annex.

- A guideline covering the principles of selection of appropriate remediation technique should be issued.

Several other regulations, which are indirectly related to soil contamination, have been enacted in recent years. However, due to institutional problems, their implementation remains very low. One of the regulations is the Environmental Auditing Regulation (2002), whose objective is to regulate the principles and methods of environmental auditing of facilities, beginning with their construction, operation and production including waste management and disposal. The regulation presents a legal framework for the quality of work and practices carried out during environmental autiting, qualifications of auditors, responsibilities of facility owner, and tasks and authorities of auditing agencies. According to the regulation, the facilities are responsible to fill up a facility activity information form, which is periodically send to the Ministry, to keep related records and to maintain an internal environmental auditing programme on a yearly basis. The facility activity information form includes knowledge about the composition, amount of stored, consumed and produced raw material and chemicals, type of storage and disposal of wastes and their amount and composition, types and results of industrial accidents. Thus, with the implementation of the Environmental Auditing Regulation, the identification and especially registration of contaminated and suspected polluted sites will be easier.

Another regulation, which includes issues on monitoring and prevention on hazardous substances in water, sediment and soil is the Regulation on Conrol of Pollution Caused by Hazardous Materials in and Around the Aquatic Environment (2005). The objective of this regulation is to determine, prevent and progressively reduce the pollution in aquatic environment. Direct discharge of hazardous substances containing wastewater into the groundwater is forbitten. Other helpful regulations are the Regulation on Waste Batteries and Accumulators (2004), the Medical Waste Control Regulation (2005), etc. 


\section{Current Status of Contaminated Sites in Turkey}

\subsection{Sources of Soil Pollution}

According to a working paper of Eighth Five-Year National Development Plan, main sources of pollution are illegal waste dumping sites, as well as municipal and industrial waste disposal sites (State Planning Organization, 2001). Especially industrial wastes, either buried illegal or disposed off in temporary storage sites close to the factory, cause to contamination of both soil and groundwater. Statistical data of the Turkish Statistical Institute (TUIK) presents that $47,3 \%$ of disposed industrial waste was disposed into the sea, lake or river, $20 \%$ was disposed off in municipal dumping sites, 10,9\% was controlled landfilled, 9,3\% was stored in the field of establishments, 2,4 \% was incinerated and 10,1\% was disposed off by other methods in $2004.60 \%$ of total disposed industrial waste belonged to the basic metal industries, followed by the non-metallic mineral industry (14\%), manufacture of food and beverages industry (13\%) and manufacture of chemicals and chemical products industry (5\%) (Turkish Statistical Institute, 2006).

Considering hazardous wastes, the regulation encourages their reuse and recycling. However, the number of hazardous waste treatment and disposal plants is very low. Therefore, industrial hazardous wastes are generally legally or illegally disposed off, incinerated or sold, rather than recycled. According to the data of Turkish Statistical Institute, $67 \%$ of the total amount of hazardous waste produced by the manufacturing industry was controlled landfilled, $21 \%$ was incinerated, $7 \%$ was stored within the establishment field, $2 \%$ was disposed off in municipal dumping sites and $3 \%$ was disposed off by other methods in 2004 (Turkish Statistical Institute, 2006).

The principal management option adopted for clinical waste management is incineration (Okumuş, 2002). Similarly, incinerators used for incineration of clinical wastes are mostly available for the waste management of metropolitan municipalities, due to their limited number (six such facilities operating in Turkey). Thus, clinical wastes, which are separately collected, are mostly disposed off with municipal refuse. $38,9 \%$ of clinical wastes was disposed off in municipal dumping sites, 20,7 \% was controlled landfilled, 20,5\% was incinerated, 12,4 \% was buried, 7,5 \% was burned in 2003 (State Planning Organization, 2006b)

The waste management in Turkey has improved especially in aspects of waste collection, transport and disposal. However, recycling rates are still low and recovery of wastes very limited, due to the limited numbers of waste treatment plants. The number of composting plants has increased from two in 1994 to five in 2004 (Turkish Statistical Institute, 2006). Additionally, there are three incineration plants and sixteen controlled landfills (State Planning Organization, 2006b; Turkish Statistical Institute, 2006). Since the awareness of sanitary landfilling of solid wastes increased in recent years, especially by metropolitan municipalities or municipalities in touristic regions, other sanitary landfills are under construction or are planned to be constructed. However, soil and groundwater pollution mainly occurs from uncontrolled dumping sites or other illegal burials. There are over 3200 municipalities, which dispose off their wastes in dumping sites with very limited or no leachate control. The amount of solid waste collected in municipalities in 2004 was 24,2 million tonnes, of which $65,3 \%$ was disposed off in municipal dumping sites, 28,9\% was disposed off in controlled landfills, 1,6 \% was disposed off by burial, 1,4 \% was treated in composting plants, $0,4 \%$ was disposed off into lakes, and river and $0,3 \%$ was disposed off by burning in open areas (Turkish Statistical Institute, 2006). 
Besides industrial waste disposal sites, industrial facilities causes to pollution due to handling losses, leakages from raw material or product storage tanks and pipelines, and accidents. Among industries, the chemical industry and metal working industry are the most polluting industries followed by the oil industry (refineries). Other activities resulting in the contamination of soil in Turkey are mining and energy production activities. Generally mine tailing disposal sites have no lining or drainage systems. Considering power plants for energy production, disposal of their ashes is very problematic. For energy production, the amount of waste generated increased from 18,8 million tonnes in 2000 to 26,4 million tonnes in 2004, despite the reduction of its share in waste production from $26 \%$ to $24 \%$; the share of municipal waste and manufacturing industry is $40 \%$ and $36 \%$ respectively (Turkish Statistical Institute, 2006). Generally, in Turkey, both mine tailings and coal ashes are stored within the establishment under uncontrolled conditions.

\subsection{Contaminated Sites in Turkey}

The problem of polluted sites started to emerge especially in heavily industrialized regions of Turkey. However, an inventory of contaminated sites is not maintained (State Planning Organization, 2006b). Currently, identification of any contaminated site is not based on a certain systematic approach. Sites are mostly identified after some potential problems become obvious and public, as a result of the efforts of local authorities or concerned citizens (NATO, 2002). The number of contaminated sites is expected to be in the range of 1000-1500, of which $5-10 \%$ are believed to be sites requiring remediation (Ünlü, 2006).

Soil pollution incidents, which became public, are mostly due to illegal disposal of industrial wastes, oil leakages resulting from accidental spill at oil storage tanks or pipelines, metal leaching from disposed metal ore processing residues and waste disposal sites. Remedial measures were carried out for very few of the contaminated sites. Therefore, some information about the contaminated sites and the remediation techniques used exists officially. However, there is no statistical data about formerly used remedial technologies and methods. Several publicly known soil pollution incidents are given below.

\section{Tuzla Orhanli, Istanbul}

The soil pollution incident in Tuzla Orhanli, one of the most publicly known incidents relies on the discovery of 640 toxic barrels in Tuzla Orhanli, a town near Istanbul, in March 2006. Samples taken from the site were analyzed by the Scientific and Technological Research Council of Turkey (TÜBITAK). The barrels, which also included hazardous phenolic compounds, were illegally buried two or three years ago by one or more chemical companies. Some barrels, which were found open on purpose, caused to the contamination of soil. Almost within a month, all 640 barrels and 2000 sacks full with contaminated soil were removed from site very carefully by a team from Izmit Waste Treatment, Incineration and Recyling Co. Inc. (IZAYDAS) and transported with special container trucks to the IZAYDAS hazardous waste treatment and disposal plant. IZAYDAS facilities are the only licensed hazardous waste disposal facility in Turkey. Remediation of contaminated site was mainly based on the incineration of both toxic barrels and highly contaminated soil. 


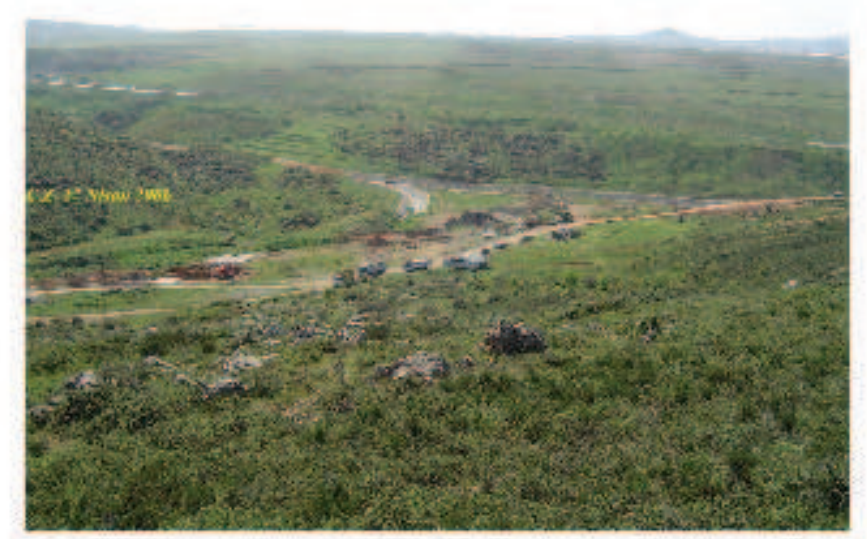

Fig. 1. A view of the investigation at the contaminated site in Tuzla Orhanli (Zanbak, 2006)

\section{Cayirova Gebze Incident}

Cayirova Gebze incident was a subject of the media in the same period of the Tuzla incident. Five barrels, full with asbestos, were found together with some other wastes near a village close to Cayirova Gebze. The Environmental Protection Department of the Kocaeli Greater Municipality took the necessary precautions and the team from IZAYDAS, which were informed, transported the barrels for inspection.

\section{BOTAS Pipeline Incident Near Ataturk Dam}

The leakage of crude oil from the Batman-Yumutalik pipeline of the Petroleum Pipeline Corporation (BOTAS) near the Ataturk Dam is among the important accidental soil pollution incidents. In April 2005, about 20-25 thousand barrels of crude oil leaked out and caused to pollution in the bay of Yiginak village and shore of Baglica village and surrounding soil, near Sanliurfa. While the pipeline was repaired, the dispersion of oil in the lake was prevented and afterward collected with the help of barriers. About 500 tons of contaminated soil were removed and transported to a site of 20 acres. The less contaminated soil was cleaned-up with a bioremediation method at the technically arranged site. The highly polluted soil, on the other hand, was transported together with other oily wastes to IZAYDAS incineration plant.

\section{Kocaeli Earthquake Incident}

In August 1999, the earthquake, with a magnitude of 7,4 MW, struck the Kocaeli and Sakarya provinces in north western Turkey. The affected region is one of most economically dynamic regions. Industries, which were damaged, were the petrochemical industry, automotive industry and other industrial facilities like paper mills, steel mills, cement, textile and pharmaceutical factories, etc. Among the state-owned petrochemical complexes the heaviest damage occurred at the TUPRAS refinery itself and associated tank farm with crude oil and product jetties. Six tanks of varying sizes in the tank farm of 112 tanks were damaged due to ground shaking and fire. Considering the IGSAS fertilizer factory, 
ammonia processing and packing units were partially and the administration building extensively damaged. The PETKIM petrochemical facility had limited damage. Besides structural damages at many facilities and factories, other important ones were the silo collapses at the SEKA paper mill, storage rack collapse, toxic releases from mixing chemicals and damaged piping at the Toprak pharmaceutical firm, damaged tanks at the AKSA chemical installation in Yallova, which was associated with leakage of chemicals. Under such catastrophic conditions the contamination of soil and water resources as a result of leakage from storage tanks, pipelines etc is mostly inevitable (Erdik, 2007).

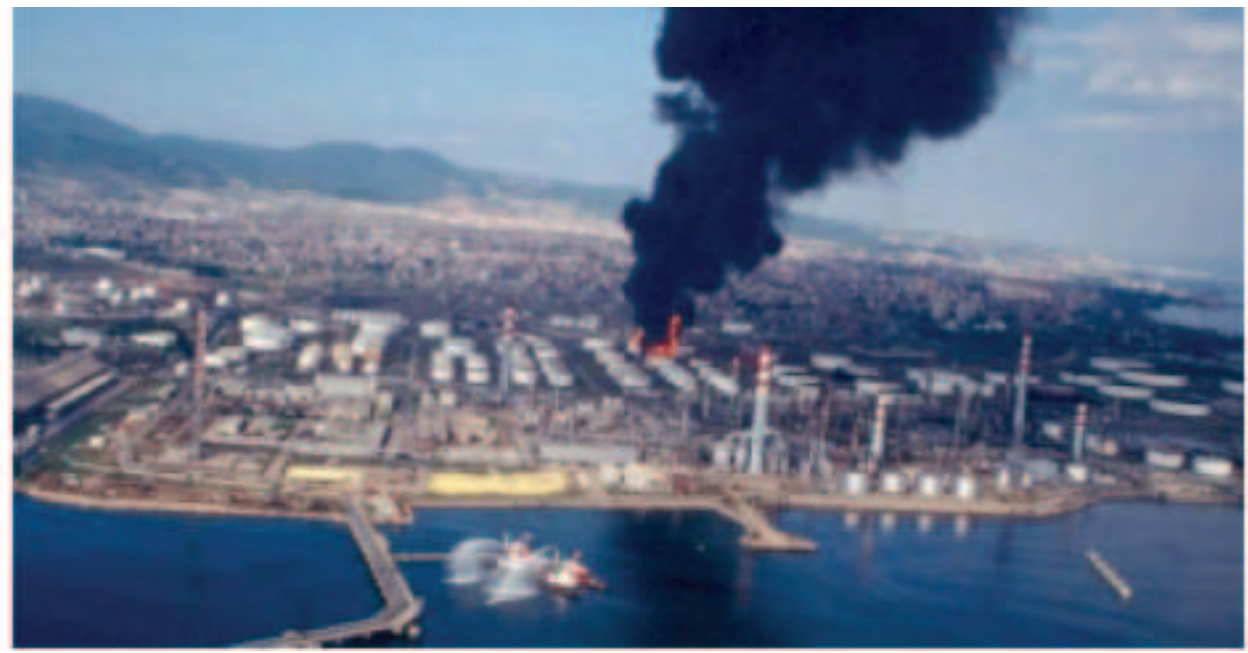

Fig. 2. A view of the fire in TUPRAS petrochemical complex (Erdik, 2007)

\section{Beykan Oil Field Site}

Another petroleum hydrocarbon pollution of soil and water resources occurred at the Beykan Oil Field site, which is enclosed by the watershed of a medium size dam. The reason of pollution was the oil spills at 38 oil producing wells, which are located within the protection zone surrounding the dam's reservoir. Evaluation of available spill data between 1989 and 1995 revealed that a total of 252 recorded spills resulted in a net spill of 395 tons. Major types of oil spills were identified as well heads, return lines and power oil lines. Analyses of 211 soil samples for total petroleum hydrocarbons revealed a concentration range between 600 and $115500 \mathrm{mg} / \mathrm{kg}$ with a mean concentration of $20300 \mathrm{mg} / \mathrm{kg}$ (Ünlü and Demirekler, 2000). In addition to soil and possible reservoir water pollution problems, another primary concern at this site is pollution of the Midyat aquifer due to injection of nearly 20 million $\mathrm{m}^{3}$ of formation water between the years of 1971 and 1996. Formation water contains high amounts of brine (containing $3000 \mathrm{mg} \mathrm{Cl} / \mathrm{L}$ and $6500 \mathrm{mg}$ TDS /L) and some emulsified oil (500 mg/L) (NATO, 1998).

\section{Incirlik PCB Contaminated Soils Site}

The contamination at Incirlik was due to PCB oil leaking from storage drums at a military reutilization yard during its operation between 1970 and 1988. In 1991 the contaminated soil was excavated and stored in approximately 300 drums and in a pile. Estimated PCB- 
contaminated soil volume is $1600 \mathrm{~m}^{3}$. PCB concentrations measured in composite soil samples range up to $750 \mathrm{ppm}$ (NATO, 1998). The NATO report indicates that incineration and solidification/stabilization were evaluated for the remediation of contaminated soil; however which one was used is not known.

\section{Chromium Ore Processing Residue Dump Site}

Another soil pollution incident reported by NATO (1998) is the chromium ore processing residue dump site. Chromium ore processing residues, which were produced by a chromate production facility, were dumped at a temporary dump site near the factory. Cr (VI) leaching from the residues, containing nearly $25000 \mathrm{ppm}$ of total chromium, caused to the contamination of soil and groundwater.

\section{Toxic Barrels of Samsun and Sinop}

The discovery of 392 barrels at the Black Sea coastline in 1988 is one of the first soil pollution incidents in Turkey. Investigations revealed that the barrels belonged to the Italians. These barrels were thrown into the Black Sea by an Italian Ship, which was carrying about three thousand toxic barrels. About 240 of barrels have been in storage in Alacam near Samsun and the remaining in Soguksu Sinop. Despite the fact that the barrels belonged to Italy, the barrels could not be send back to Italy for 18 years. Finally, it was planned that the toxic barrels are sent to disposal facilities in Germany with a support of the Turkish Cement Manufacturers' Association, which includes Italian companies as well. IZAYDAS, which took the barrels from Samsun and Sinop, transported the barrels to Izmir for further shipment to Europe for their disposal. Unfortunately, about 150 barrels were found empty thus indicating to a contamination of both soil and water resources.

\section{Other Suspected Contaminated Sites}

There were some complains about barrels, which were temporary stored by Turkish Petroleum Refineries Corporation (TUPRAS) at a site in Batman for years. These barrels, over hundred pieces, contain chemicals from the petroleum refinery. Competent of TUPRAS stated that the barrels were going to be removed by IZAYDAS. There are many other storage sites, which are accepted as temporary sites, but rather work permanently. According to a hazardous waste management report written by Zanbak and Bayazit Tugal (1997), there is a need for the registration, investigation and rehabilitation of these temporary hazardous wastes disposal sites.

Municipal solid waste dumping sites, especially those used by metropolitan or greater municipalities, cause to significant pollution of soil and groundwater, which is well known. In Turkey, most of the time, commercial and industrial wastes are disposed off together with domestic solid wastes, thus increasing the contamination potential of leachate. Most of the municipal dumping sites do not have a drainage system for leachate collection and a clay layer to prevent leaching into soil and groundwater. When the use of dumping sites is completed, their rehabilitation is carried out. Since measures for the collection and treatment of leachate are generally not taken the contamination of soil and groundwater continues. There are over 3200 municipalities in Turkey, but the number of sanitary landfills and landfills with EIA approval is not over fifty. Under these circumstances it is not difficult to estimate the number of dumping sites suspected as contaminated sites. Some closed or still operating municipal solid waste dumping sites, well known for conditions are Yakacik (with 
a capacity of $600000 \mathrm{~m}^{3}$ ), Ümraniye (with a capacity of 2 million $\mathrm{m}^{3}$ ) and Halkalı (with a capacity of 10 million $\mathrm{m}^{3}$ ) dumping sites of Istanbul (closed), Mamak dumping site of Ankara (operating), Cigli, Uzundere, Buca, Isikkent, Güzelbahçe, and Gaziemir dumping sites of Izmir (closed).

\section{Conclusion}

Since 1990s Turkey has made significant environmental progress with reforms in institutional and legislative frameworks. The Ministry of Environment (now the Ministry of Environment and Forestry) was created and various environmental legislations were adopted. As a part of national development plan, the National Environmental Action Plan was developed. Soil protection and pollution issues were included in this plan and the need for the registration of environmental pollution was emphasized.

Several regulations for the control and prevention of soil pollution were enforced, however there are problems related to their implementation. Despite the enforcement of both Hazardous Waste Control Regulation and Solid Waste Control Regulation, there is still a need for improvements in the waste management system. For the monitoring of waste generation activities and pollution potentials of industries, a complete and correct filling of annual waste declaration form is very important. In addition, the information of the facility activity form required by the Environmental Auditing Regulation will support the development of a waste inventory and the identification of the needs for necessary waste treatment and disposal facilities. The data provided from the implementation of both regulations will also facilitate the identification and registration of contaminated sites.

The Soil Pollution Control Regulation is relatively new and requires a major revision for its practicality on issues like identification, investigation, monitoring and clean-up of contaminated sites. The lists for limiting values of inorganic and organic contaminants need to be extended and indicative values, soil remediation intervention values and target values for all contaminants to be included. Programmes providing a systematic approach for the identification, monitoring and remediation of contaminated sites are needed to be developed.

The Ministry of Environment and Forestry, which is aware on these deficiencies of regulation and current practices of contaminated sites, carries out a project on "the Development of a Management System for Point Source Contaminated Sites," together with the Environmental Engineering Department of Middle East Technical University. The purpose of this project is to determine the necessary points of the Soil Pollution Control Regulation to be amended and publish a conceptually and technically revised Soil Pollution Control Regulation, to adopt specific soil quality standards based on land use, to develop a contaminated sites identification and registration system, a contaminated site evaluation system and a computer software for the contaminated sites information system. It also aims to develop technical guidelines for the investigation, risk evaluation, clean-up and monitoring of contaminated sites. With the accomplishment of the project a contaminated site management system will have been developed, which is of upper most need.

Especially in heavily industrialized regions of Turkey problems with respect to contaminated sites has increased. Main sources of pollution are industrial facilities, disposal of municipal and industrial wastes, mining and energy production activities. Currently, an inventory for contaminated sites does not exist. However, soil pollution incidents, which became public, are mainly illegal dumps and temporary industrial waste disposal sites. 
Detailed information on the size of contaminated site, the concentration and characteristics of pollutants and impacts of pollutants on the groundwater and other receptors is mostly not available. Similarly, knowledge about the measures taken and the remediation methods/techniques used is limited to recent contaminated sites. In general, the contaminated soil is removed from the area and either incinerated or controlled landfilled. Soil contaminated by hazardous substances is mostly incinerated at the IZAYDAS incineration plant. For the remediation of petroleum contaminated soil, bioremediation is also considered besides incineration. Municipal disposal sites are mostly rehabilitated after closure. However, any remedial action for the control of underground contaminant transport is generally not carried out.

The importance of soil pollution prevention and remediation of contaminated sites will especially increase in future with the recognition of the groundwater pollution problem. There is an accelerated degradation of groundwater quality and a raised withdrawal in recent years. The use of groundwater resources for domestic water supply purposes, on the other hand, will make the situation more serious. Since contaminants are wider dispersed in groundwater rather than soil, increasing the costs of remediation, the protection of groundwater resources and prevention of pollution will become environmental issues of high priority.

\section{References}

Commission of the European Communities (2006). Turkey 2006 Progress Report, Commission Staff Working Document, pp. 65-68, SEC(2006) 1390, Brussels

Erdik, M. (2007). Report on 1999 Kocaeli and Düzce (Turkey) Earthquakes, pp. 30-33, Bogazici University, Department. of Earthquake Engineering, Cengelköy, Istanbul, Turkey, http://www.koeri.boun.edu.tr/depremmuh/eqspecials/kocaeli/Kocaelireport.pdf (last accessed in August 2007)

Keskin, S. (2001). Gateway to Land and Water Information: Turkey National Report, pp. 7-8, Head of Data Collection and Analysis, Department of Soil \& Water Resources National Information Centre, General Directorate of Rural Services, Turkey, http://www.fao.org/ag/agl/swlwpnr/reports/y_nr/z_tr/tr.htm (last accessed in July 2007)

NATO, North Atlantic Treaty Organization, Committee on the Challenges of Modern Society (2002). Evaluation of Demonstrated and Emerging Technologies for the Treatment of Contaminated Land and Groundwater (Phase III), NATO/CCMS Pilot Study, 2001 Annual Report, Number 250, pp. 251-253, EPA 542-R-02-001.

NATO, North Atlantic Treaty Organization, Committee on the Challenges of Modern Society (1998). Evaluation of Demonstrated and Emerging Technologies for the Treatment of Contaminated Land and Groundwater (Phase III), NATO/CCMS Pilot Study, 1998 Annual Report, Number 228, , pp. 108-113, EPA 542-R-98-002.

OECD Working Party on Environmental Performance (2000), Environmental Performance Reviews (1 ${ }^{\text {st }}$ Cycle), Conclusions and Recommendations 32 Countries (1993-2000), pp. 245-252, WPEP

Okumuş, K.; (Ed.) (2002). Turkey's Environment, A Review and Evaluation of Turkey's Environment and its Stakeholders, The Regional Environmental Center for Central and Eastern Europe, pp. 10-25, ISBN 9639424099, Szentendre, Hungary

Ongan, S. E. (ED) (1997). Land Use and Management of Coastal Areas, NEAP, State Planning Organization, ISBN 9751916984, Ankara, Turkey, 
htpp://ekutup.dpt.gov.tr/cevre/eylempla/arazikul.pdf (last accessed in July 2007) (in turkish)

State Planning Organization (2006a). Use and Management of Soil and Water Resources, Ninth National Development Plan, pp. 87-99, DPT, Ankara, Turkey, htpp://plan9.dpt.gov.tr/oik25_topraksu/Rapor.doc\#_Toc132780616 (last accessed in July 2007) (in turkish)

State Planning Organization (2006b). Environment, Ninth National Development Plan, pp. 20-25, DPT, Ankara, Turkey, htpp://plan9.dpt.gov.tr/oik22\%5Fcevre/cevre.pdf (last accessed in July 2007) (in turkish)

State Planning Organization (2001). Use and Management of Watershed, Eighth National Development Plan, DPT: 2555, pp. 97-114, ISBN 9751926386, Ankara, Turkey, htpp://ekutup.dpt.gov.tr/suhavza/oik571.pdf (last accessed in July 2007) (in turkish)

State Planning Organization (1998). National Environmental Action Plan, DPT.YBM, ISBN 97519-1995-X, Ankara Turkey, htpp://ekutup.dpt.gov.tr/cevre/eylempla/neap.html (last accessed in July 2007)

Turkish Standard Institute (2006). Environmental Statistics Compendium of Turkey II, Environmental Statistics Group, TSI: 3011, pp. 70-83, ISBN 9751938651, Prime Ministry, Ankara, Turkey.

Ünlü, K. (2006). Tour de Table: The Situation of Contaminated Sites in Turkey , Country Presentation at the NATO/CCMS Pilot Study Workshop Prevention and Remediation in Selected Industrial Sectors: Small Sites in Urban Areas, 4-7 June 2006, Athens, Greece, organised by the North Atlantic Treaty Organization Committee on the Challenges of Modern Society, pp. 4-5, www.cluin.org/athens/download/Tour_de_Table/Turkey_Tour_de_Table.pdf

Ünlü, K. \& Demirekler, E. (2000). Modeling Water Quality Impacts of Petroleum Contaminated Soils in a Reservoir Catchment, Water, Air and Soil Pollution, Vol. 120, No. 1-2, May 2000, 169-193, ISSN 0049-6979

Zanbak, C. \& Bayazit Tugal I. (1997). Hazardous Waste Management, NEAP, State Planning Organization, pp. 21-38, ISBN 9751916763, Ankara, Turkey, htpp://ekutup.dpt.gov.tr/cevre/eylempla/zanbakc.pdf (last accessed in July 2007) (in turkish)

Zanbak, C. (2006). Industrial Waste Management and Turkey- Problems and Solutions (1996-2006), Hazardous Wastes: Human and Environmental Health Mini Symposium, Turkish Society of Toxicology, 30 May 2006, Ankara, Turkey. (in turkish) 


\section{ANNEX 1}

\section{Natural Resource Management (State Planning Organization, 1998)}

\begin{tabular}{|c|c|}
\hline Areas of Action & Options \\
\hline Policies & $\begin{array}{l}\text { 1. Diffusion and planning of rural development policies } \\
\text { 2. Agricultural support policies integrated with efforts to preserve land } \\
\text { resources } \\
\text { 3. Preparation of action plans for the prevention of soil erosion, } \\
\text { desertification and pollution, especially in the GAP region; } \\
\text { 4. Using soils according to their suitability classification }\end{array}$ \\
\hline $\begin{array}{l}\text { Institutional } \\
\text { Reform }\end{array}$ & $\begin{array}{l}\text { 5. Reorganization of the central and peripheral units of the Ministry of } \\
\text { Agriculture and Rural Services and the Ministry of Forestry } \\
\text { 6. Making public research agencies and routine analysis laboratories } \\
\text { more efficient and effective } \\
\text { 7. Ensuring that the service delivery by the General Directorate of } \\
\text { Rural Services is carried out by a separate organization than those in } \\
\text { charge of research, data collection and training } \\
\text { 8. Formation of basin management units and executive boards } \\
\text { 9. Rearrangement of the rights, duties and responsibilities of the Union } \\
\text { of Chambers of Agriculture } \\
\text { 10. Redefinition of the rights, authority and responsibilities of village } \\
\text { administrations; strengthening of village unions; democratization of } \\
\text { administration } \\
\text { 11. Preparation of soil conservation and land improvement action plans } \\
\text { at the regional level } \\
\text { 12. Establishment of a unit in charge of research, control of techniques } \\
\text { and equipment as well as calibration of equipment which are used } \\
\text { for agricultural combat. }\end{array}$ \\
\hline $\begin{array}{l}\text { Legislative } \\
\text { Arrangements }\end{array}$ & $\begin{array}{l}\text { 13. Amendment of Articles } 44 \text { and } 45 \text { of the Constitution; } \\
\text { 14. Enactment of Soil Conservation and Land Improvement Laws; } \\
\text { 15. Enactment of Regulation on the Control of Soil Pollution; } \\
\text { 16. Revision of Acts nos. } 4070,4071 \text {, and } 4072 \\
\text { 17. Revision of the Act on Cooperatives; } \\
\text { 18. Updating of the Village Act; } \\
\text { 19. Revision of the articles of the Land Act and Civil Code that permit } \\
\text { the fragmentation and non-agricultural use of agricultural lands; } \\
\text { 20. Revising the Act on Mining to ensure that mining enterprises } \\
\text { prepare and implement land rehabilitation programs after their } \\
\text { extraction activities; } \\
\text { 21. Revising the institutional laws of the DSI, GDA, and GDRS to permit } \\
\text { integrated work at the catchment basin level }\end{array}$ \\
\hline
\end{tabular}

Table 2. Options for the Protection and Management of Land/Soil Resources. 


\begin{tabular}{|c|c|}
\hline Areas of Action & Options \\
\hline Policies & $\begin{array}{l}\text { 22. Diffusion and planning of rural development policies } \\
\text { 23. Agricultural support policies integrated with efforts to preserve land } \\
\text { resources } \\
\text { 24. Preparation of action plans for the prevention of soil erosion, } \\
\text { desertification and pollution, especially in the GAP region; } \\
\text { 25. Using soils according to their suitability classification }\end{array}$ \\
\hline $\begin{array}{l}\text { Institutional } \\
\text { Reform }\end{array}$ & $\begin{array}{l}\text { 26. Reorganization of the central and peripheral units of the Ministry of } \\
\text { Agriculture and Rural Services and the Ministry of Forestry } \\
\text { 27. Making public research agencies and routine analysis laboratories } \\
\text { more efficient and effective } \\
\text { 28. Ensuring that the service delivery by the General Directorate of } \\
\text { Rural Services is carried out by a separate organization than those in } \\
\text { charge of research, data collection and training } \\
\text { 29. Formation of basin management units and executive boards } \\
\text { 30. Rearrangement of the rights, duties and responsibilities of the Union } \\
\text { of Chambers of Agriculture } \\
\text { 31. Redefinition of the rights, authority and responsibilities of village } \\
\text { administrations; strengthening of village unions; democratization of } \\
\text { administration } \\
\text { 32. Preparation of soil conservation and land improvement action plans } \\
\text { at the regional level } \\
\text { 33. Establishment of a unit in charge of research, control of techniques } \\
\text { and equipment as well as calibration of equipment which are used } \\
\text { for agricultural combat. }\end{array}$ \\
\hline $\begin{array}{l}\text { Legislative } \\
\text { Arrangements }\end{array}$ & $\begin{array}{l}\text { 34. Amendment of Articles } 44 \text { and } 45 \text { of the Constitution; } \\
\text { 35. Enactment of Soil Conservation and Land Improvement Laws; } \\
\text { 36. Enactment of Regulation on the Control of Soil Pollution; } \\
\text { 37. Revision of Acts nos. } 4070,4071 \text {, and } 4072 \\
\text { 38. Revision of the Act on Cooperatives; } \\
\text { 39. Updating of the Village Act; } \\
\text { 40. Revision of the articles of the Land Act and Civil Code that permit } \\
\text { the fragmentation and non-agricultural use of agricultural lands; } \\
\text { 41. Revising the Act on Mining to ensure that mining enterprises } \\
\text { prepare and implement land rehabilitation programs after their } \\
\text { extraction activities; } \\
\text { 42. Revising the institutional laws of the DSI, GDA, and GDRS to permit } \\
\text { integrated work at the catchment basin level }\end{array}$ \\
\hline $\begin{array}{l}\text { Economic \& } \\
\text { Financial } \\
\text { Measures }\end{array}$ & $\begin{array}{l}\text { 43. Ensuring farmers' contribution to land improvement investments } \\
\text { Seeking the contribution of mining industries for land rehabilitation } \\
\text { 44. Charging land improvement fees to polluters }\end{array}$ \\
\hline
\end{tabular}

Table 2. Options for the Protection and Management of Land/Soil Resources. (continued) 


\begin{tabular}{|c|c|}
\hline Areas of Action & Options \\
\hline $\begin{array}{l}\text { Economic \& } \\
\text { Financial } \\
\text { Measures }\end{array}$ & $\begin{array}{l}\text { 45. Ensuring that monetary incentives introduced by Act no. } 4122 \text { are } \\
\text { first channeled to soil conservation and land improvement works in } \\
\text { water catchments } \\
\text { 46. Reconsideration of incentives for pesticide use }\end{array}$ \\
\hline $\begin{array}{l}\text { Education- } \\
\text { Training }\end{array}$ & $\begin{array}{l}\text { 47. Development and wider use of soil conservation related in-service } \\
\text { training programs in related public organizations and agencies } \\
\text { 48. Giving soil conservancy and land improvement training to village } \\
\text { group technicians } \\
\text { 49. Support to professional and voluntary organizations in their } \\
\text { activities for soil conservation and land improvement } \\
\text { 50. Diffusion of extension activities in line with the cultural and social } \\
\text { conditions of the region concerned; conduct of joint training } \\
\text { programs with farmers; implementation of advanced techniques } \\
\text { 51. Attachment of extension units to research institutes; coordinated } \\
\text { work performance of research-extension-agricultural combat units }\end{array}$ \\
\hline Participation & $\begin{array}{l}\text { 52. Institutionalization of cooperation between the related ministries } \\
\text { and professional and voluntary organizations } \\
\text { 53. Participation of the farmers of a region in the planning and } \\
\text { implementation of integrated eco-basin management plans by } \\
\text { exercising specific rights and undertaking duties and responsibilities } \\
\text { 54. Strengthening of the committee stipulated by the Regulation on } \\
\text { Pesticide Licenses with specialists from different fields }\end{array}$ \\
\hline Techniques & $\begin{array}{l}\text { 55. Establishment and use of remote sensing/geographical information } \\
\text { systems; } \\
\text { 56. Diffusion of land compacting works; } \\
\text { 57. Expansion of the scope of EIA to cover the assessment of the } \\
\text { infrastructure investments of public organizations; } \\
\text { 58. Monitoring and supervision of land and agricultural input use } \\
\text { 59. Expansion of the scope of EIA to cover the issue of non-agricultural } \\
\text { use of agricultural lands } \\
\text { 60. Limitation of area under tobacco cultivation; } \\
\text { 61. Control of the use of phosphorous fertilizers; } \\
\text { 62. Preparation and implementation of programs designed for the } \\
\text { encouragement } \\
\text { of integrated pest management; establishment of early warning } \\
\text { schemes; } \\
\text { 63. Inspection of agricultural pesticide producers and dealers; } \\
\text { 64. Expansion of fodder crop culture; }\end{array}$ \\
\hline
\end{tabular}

Table 2. Options for the Protection and Management of Land/Soil Resources. (continued) 
Areas of Action

Techniques

R \& D irrigation purposes. substances; limits equipment

\section{Options}

65. Control of the importation and use of hormones and carcinogenic

66. Abandonment of the practice of follow with the exception of localities where this practice is scientifically proven as necessary

67. Elimination of differing practices in the field of chemical residue

68. Updating land capacity classifications;

69. Identification of tilling techniques and the methods of agricultural inputs (water, fertilizers and pesticides) with respect to land characteristics and local levels not to harm soils and development of environmentally friendly technologies;

70. Supervision of the producers of agricultural pesticides and

71. Identification of fertilizer compositions suitable to local conditions and environmental impacts of fertilizers specific to locations

72. Development of techniques in order to use drainage water for

Table 2. Options for the Protection and Management of Land/Soil Resources. (continued) 


\section{ANNEX 2}

\section{The Urban Environment (State Planning Organization, 1998)}

\begin{tabular}{|c|c|}
\hline Areas of Action & Options \\
\hline Policies & $\begin{array}{l}\text { 1. Emphasis on minimizing, recycling and recovering wastes; } \\
\text { 2. Rehabilitation of old waste dumps; } \\
\text { 3. Emphasis on sanitary landfills \& hazardous waste treatment. }\end{array}$ \\
\hline $\begin{array}{l}\text { Institutional } \\
\text { Reform }\end{array}$ & $\begin{array}{l}\text { 4. Establishment of "Waste Exchange" at national and regional levels; } \\
\text { 5. Formation of "Hazardous Waste Management" units at regional } \\
\text { level; } \\
\text { 6. Establishment of "Emergency Management Centers"; } \\
\text { 7. Establishment of "Waste Management Units" with special budgets } \\
\text { within the boundaries of greater municipalities. }\end{array}$ \\
\hline $\begin{array}{l}\text { ative } \\
\text { gements }\end{array}$ & $\begin{array}{l}\text { 8. Enactment of new regulations on industrial accidents, cases } \\
\text { requiring urgent intervention, and hazardous waste transportation; } \\
\text { 9. Rearrangement of authority and responsibility sharing among } \\
\text { relevant organizations in a coordinated manner, and introduction of } \\
\text { a functional division of labor; } \\
\text { 10. Development of guidelines for the storage of hazardous wastes; } \\
\text { 11. Elimination of inconsistent terms used in relevant legislation; } \\
\text { 12. Legal arrangements for introducing eco-labeling; } \\
\text { 13. Adherence to international agreements on hazardous waste } \\
\text { management; } \\
\text { 14. Amend Municipal Revenues Law (No. 2464) to increase cost-sharing } \\
\text { for infrastructure investment; } \\
\text { 15. Revise legislation to allow for more private sector participation in } \\
\text { solid and hazardous waste management; } \\
\text { 16. Amend Regulation on Solid Waste Control to increase flexibility in } \\
\text { lining standards at sanitary landfills where there is no risk of } \\
\text { leaching; } \\
\text { 17. Allow municipalities to enforce Hazardous Waste Control } \\
\text { Regulation. }\end{array}$ \\
\hline $\begin{array}{l}\text { Economic \& } \\
\text { Financial } \\
\text { Measures }\end{array}$ & $\begin{array}{l}\text { 18. Land allocation and credit for regional resource recovery and waste } \\
\text { disposal facilities; } \\
\text { 19. Replace Environment Cleansing Tax with inflation-adjusted charges } \\
\text { based on the quantity and type of waste generated; } \\
\text { 20. Incentives for waste reduction at source; } \\
\text { 21. Applying hazardous waste disposal charges to original } \\
\text { manufacturers as well as users. }\end{array}$ \\
\hline
\end{tabular}

Table 3. Options for Solid and Hazardous Waste Management. 


\begin{tabular}{|c|c|}
\hline Areas of Action & Options \\
\hline $\begin{array}{l}\text { Education } \\
\text {-Training }\end{array}$ & $\begin{array}{l}\text { 22. Implementation of training programs on hazardous waste } \\
\text { management; } \\
\text { 23. Training of hospital personnel at all levels; } \\
\text { 24. Certification for the information and skill levels of personnel } \\
\text { employed in hazardous and medical waste management; } \\
\text { 25. Institutionalizing the information flow to the public; } \\
\text { 26. Implementation of training programs to encourage the wider use of } \\
\text { "eco-packaging". }\end{array}$ \\
\hline Participation & $\begin{array}{l}\text { 27. Support to voluntary organizations in their monitoring and project } \\
\text { based activities; } \\
\text { 28. Conduct of regional referendums on the collection, dumping and } \\
\text { elimination of hazardous wastes; } \\
\text { 29. Encouragement of persons and organizations who reduce waste at } \\
\text { the source. }\end{array}$ \\
\hline Techniques & $\begin{array}{l}\text { 30. Establishment of waste processing and disposal facilities equipped } \\
\text { with appropriate technologies; } \\
\text { 31. Support for waste producers to introduce waste minimization } \\
\text { (including packaging), recycling and disposal systems; } \\
\text { 32. Enlarging the scope of waste inventories and ensuring their } \\
\text { sustenance; } \\
\text { 33. Supporting the establishment of integrated (reuse+elimination) } \\
\text { waste processing facilities; } \\
\text { 34. Preparation of programs for the improvement of polluted areas; } \\
\text { 35. Updating of topographic maps and aerial photographs; } \\
\text { 36. Developing standards for recycled products; } \\
\text { 37. Inclusion of hazardous waste management in urban development } \\
\text { plans; } \\
\text { 38. Wider observance in public and private industries of the principles } \\
\text { of ISO 14000, Ecotex, and Triple Responsibility; } \\
\text { 39. Encouragement of "environment friendly" production and } \\
\text { consumption; } \\
\text { 40. Preparation of "Waste Management Plans" by producers in sensitive } \\
\text { receiving environments; } \\
\text { 41. Support infrastructure for the collection, transport and elimination } \\
\text { of medical waste; } \\
\text { 42. Preparation of standards for collection tanks, transport vehicles, } \\
\text { transfer stations, dumping sites and elimination facilities } \\
\text { 43. Development of standards for transportation and temporary storage } \\
\text { of hazardous wastes. }\end{array}$ \\
\hline
\end{tabular}

Table 3. Options for Solid and Hazardous Waste Management (continued) 


$\begin{aligned} & \text { Areas of Action } \\ & \text { R \& D }\end{aligned}$
$\begin{aligned} & \text { 44. Further enrichment of waste processing options; } \\ & \text { 45. Establishment of a "Processing Development Center" for reducing } \\ & \text { wastes; } \\ & \text { 46. Wider support to the R \& D work of industrial enterprises in the } \\ & \text { field of waste management; } \\ & \text { 47. Inventory of areas polluted by wastes; } \\ & \text { 48. Identification of waste dumping sites fit for urban settlements; } \\ & \text { 49. Development of technologies for the dumping, transport and } \\ & \text { elimination of medical wastes; } \\ & \text { 50. Identification of ecosystems affected by dumpsite leachate; } \\ & \text { 51. Preparation of "Glossary of Waste Management Terms"; } \\ & \text { 52. Develop transparent criteria for sanitary landfill site selection. }\end{aligned}$

Table 3. Options for Solid and Hazardous Waste Management. (continued) 


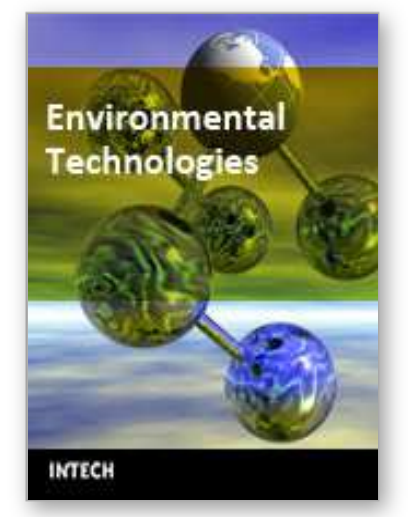

\author{
Environmental Technologies \\ Edited by E. Burcu Ozkaraova Gungor
}

ISBN 978-3-902613-10-3

Hard cover, 268 pages

Publisher I-Tech Education and Publishing

Published online 01, January, 2008

Published in print edition January, 2008

This book on Environmental Technology takes a look at issues such as air, soil and noise pollution problems, environmental quality assessment, monitoring, modelling and risk as- sessment, environmental health impact assessment, environmental management and envi- ronmental technology development. It represents institutional arrangements, financial mechanisms and some sustainable technologies. The user can always count on finding both introductory material and more specific material based on national interests and problems. The user will also find ample references at the end of each chapter, if additional information is required. For additional questions or comments the user is encouraged to contact the author.

\title{
How to reference
}

In order to correctly reference this scholarly work, feel free to copy and paste the following:

E. Burcu Ozkaraova Gungor (2008). Soil Pollution and Remediation Problems in Turkey, Environmental Technologies, E. Burcu Ozkaraova Gungor (Ed.), ISBN: 978-3-902613-10-3, InTech, Available from: http://www.intechopen.com/books/environmental_technologies/soil_pollution_and_remediation_problems_in_t urkey

\section{INTECH}

open science | open minds

\section{InTech Europe}

University Campus STeP Ri Slavka Krautzeka 83/A 51000 Rijeka, Croatia

Phone: +385 (51) 770447

Fax: +385 (51) 686166 www.intechopen.com

\section{InTech China}

Unit 405, Office Block, Hotel Equatorial Shanghai No.65, Yan An Road (West), Shanghai, 200040, China 中国上海市延安西路65号上海国际贵都大饭店办公楼405单元 Phone: +86-21-62489820

Fax: +86-21-62489821 
(C) 2008 The Author(s). Licensee IntechOpen. This chapter is distributed under the terms of the Creative Commons Attribution-NonCommercialShareAlike-3.0 License, which permits use, distribution and reproduction for non-commercial purposes, provided the original is properly cited and derivative works building on this content are distributed under the same license. 